\title{
Alppiruusun pistokkaiden juurtumiseen vaikuttavia tekijöitä
}

\author{
Marja Ylätalo \\ Helsingin yliopiston puutarhatieteen laitos, 00710 Helsinki 71
}

Factors affecting the rooting of Rhododendron cuttings

Marja Ylätalo

Department of Horticulture, University of Helsinki, 00710 Helsinki 71, Finland

\begin{abstract}
The effects of collection date and cutting treatments on rooting were studied on three of Finland's hardiest Rhododendron species (Rh. brachycarpum ssp. tigerstedti, Rh. 'Cunningham's White' and Rh. smirnowii). Cuttings were set into a medium $40 \mathrm{~cm}$ thick protected by a plastic tent which was opened for watering only after two months.

The best month for taking cuttings was January. The slow bud break made possible root initiation at the same time. In January the rooting percentage of $R h$. brachycarpum ssp. tigerstedti cuttings was 100 after treatment with $0.6 \%$ IBA (control $79 \%$ ). IBA did not enhance rooting in August, when root initiation was slow.

Benomyl applied to the basal ends of cuttings inhibited basal rot and stimulated rooting especially when used in conjunction with IBA. Basal wounding also improved the rooting percentage and the quality of roots.

The most difficult of the three Rhododendron species to root was Rh. smirnowii.
\end{abstract}

\section{Johdanto}

Ikivihreä, suurikukkainen alppiruusu (alasuku Eurhododendron) soveltuu hyvin Suomen havupuuvaltaiseen maisemaan. Alppiruusun lisääntyneeseen kysyntään on vaikuttanut sen käyttökelpoisuus nykyajan pienillä ja usein varjoisilla pihoilla. Suomessa käytettävä alppiruusumateriaali tuodaan lähes kokonaan istutuskuntoisina taimina keski-Euroopasta. Tuontitaimien, pääasiassa Rhododendron catawbiense Michx. -hybridien, ilmastonkestävyys ei kuitenkaan ole hyvä. Mustilan arboretumissa useiden vuosikymmenien aikana saadut kokemukset ovat osoittaneet, että Suomessa parhaiten menestyvät alppiruusulajit ovat Rh. brachycarpum ssp. tigerstedti Niz., Rh. caucasicum Pall. ja Rh. smirnowii Trautv.

Rhododendron-lajit lisätään yleensä pistokkaista. Alppiruusu on kuitenkin melko vaikeasti juurrutettava kasvi. Pistokkaiden juurtuminen vaatii pitkän ajan, mutta pistämisaiankohdalla on vaikutusta pistokkaiden juurtuvuuteen 
ja juurtumisnopeuteen. Käytännössä meillä saadut kokemukset alppiruusun pistokaslisäyksestä ovat vaihdelleet, mikä on osaltaan jarruttanut kotimaisen tuotannon kehittymistä.

Tämän tutkimuksen tarkoituksena oli selvittää pistämisajankohdan ja juurtumista edistävien käsittelyjen vaikutus kolmen Suomessa kestävimmäksi todetun alppiruusun pistokkaiden juurtuvuuteen.

\section{Aineisto ja menetelmät}

Alppiruusun pistokkaat kerättiin Mustilan arboretumista $\left(60^{\circ} 44^{\prime}\right.$ p.l. $20^{\circ} 29^{\prime}$ i.p.) Elimäen kunnasta neljänä ajankohtana vuonna 1976. Emokasvit olivat iäkkäitä ja kasvoivat puolivarjossa havupuumetsikön aluskasvillisuutena. Pistokkaat otettiin eri puolilta emokasveja, Rh. brachycarpum ssp. tigerstedti -lajilta samoista kolmesta yksilöstä joka kerralla, Rh. smirnowii ja $R h$. caucasicum $\times R h$. ponticum album 'Cunningham's White' -lajeilta kahdesta yksilöstä. Pistokkaiksi valittiin 5-6 cm:n pituiset versojen latvat edellisen kesän kasvua, ei kukkanupullisia. Kuhunkin pistokkaaseen jätettiin 3-4 ylinta täysikasvuista lehteä.

Pistokkaita liotettiin vuorokauden ajan $0.01 \%$ booriliuoksessa, ja sen jälkeen pistokkaiden tyviin tehtiin kaksipuolisesti $1.5 \mathrm{~cm}: \mathrm{n}$ pituiset viillot, jos toisin ei mainita. Indoli-3-voihappo- (IBA) tai/ja benomyylikäsittelyt suoritettiin kastamalla pistokkaiden tyvet liuokseen kymmeneksi sekunniksi.

Juurrutus tapahtui Viikissä kasvihuoneeseen rakennetussa muoviteltassa. Juurrutusalustana oli $40 \mathrm{~cm}$ paksu, vaalea rahkaturve $\left(\mathrm{pH}_{20} 3.8\right)$, ja juurrutusalustan lämpötila oli $+23^{\circ} \mathrm{C}$. Muoviteltta avattiin kahden kuukauden välein kastelua varten.

Havainnot juurtumisesta tehtiin kahden ja neljän kuukauden kuluttua pistämisestä, jolloin juuriston laatu arvoteltiin seuraavan asteikon mukaisesti:

1. yksittäisiä juuria enintään $5 \mathrm{kpl}$,

2. juurten lukumäärä yli 5 , pieni tai toispuolinen juuripaakku,

3. runsas, tasapuolisesti kehittynyt juuristo, kiinteä juuripaakku.

Elokuussa pistetyistä eristä havainnot tehtiin vielä seitsemän kuukauden kuluttua pistämisestä.

\section{Tulokset}

Rhododendron brachycarpum ssp. tigerstedti -lajin pistämisajankohdan vaikutus juurtuvuuteen umpinaisessa muoviteltassa ilmenee kuvasta 1 . Pistokkaat juurtuivat sitä paremmin ja nopeammin, mitä varhaisemmassa vaiheessa vuodenvaihteeseen nähden ne otettiin. Syyskesällä juurtuvuus oli heikointa.

Pistokkaiden ottoajan ja käsittelyjen yhteisvaikutuksen merkitsevyys osoitti, että käsittelyjen teho riippui pistämisajankohdasta (kuva 1). IBA lisäsi pistokkaiden juurtumista ja paransi juuriston laatua kevättalvella, mutta ei elokuussa. Parhain juurtuvuus saavutettiin keskimäärin $0.6 \%$ IBA:lla sekä yhdistetyllä IBA- ja benomyylikäsittelyllä. Auksiinikäsittely lisäsi juurten lukumäärää. Benomyylin havaittiin ehkäisevän pistokkaiden tyvien mätänemistä, joka oli yleisempää kuin kuolleiden määrä osoittaa kuvassa 1. 


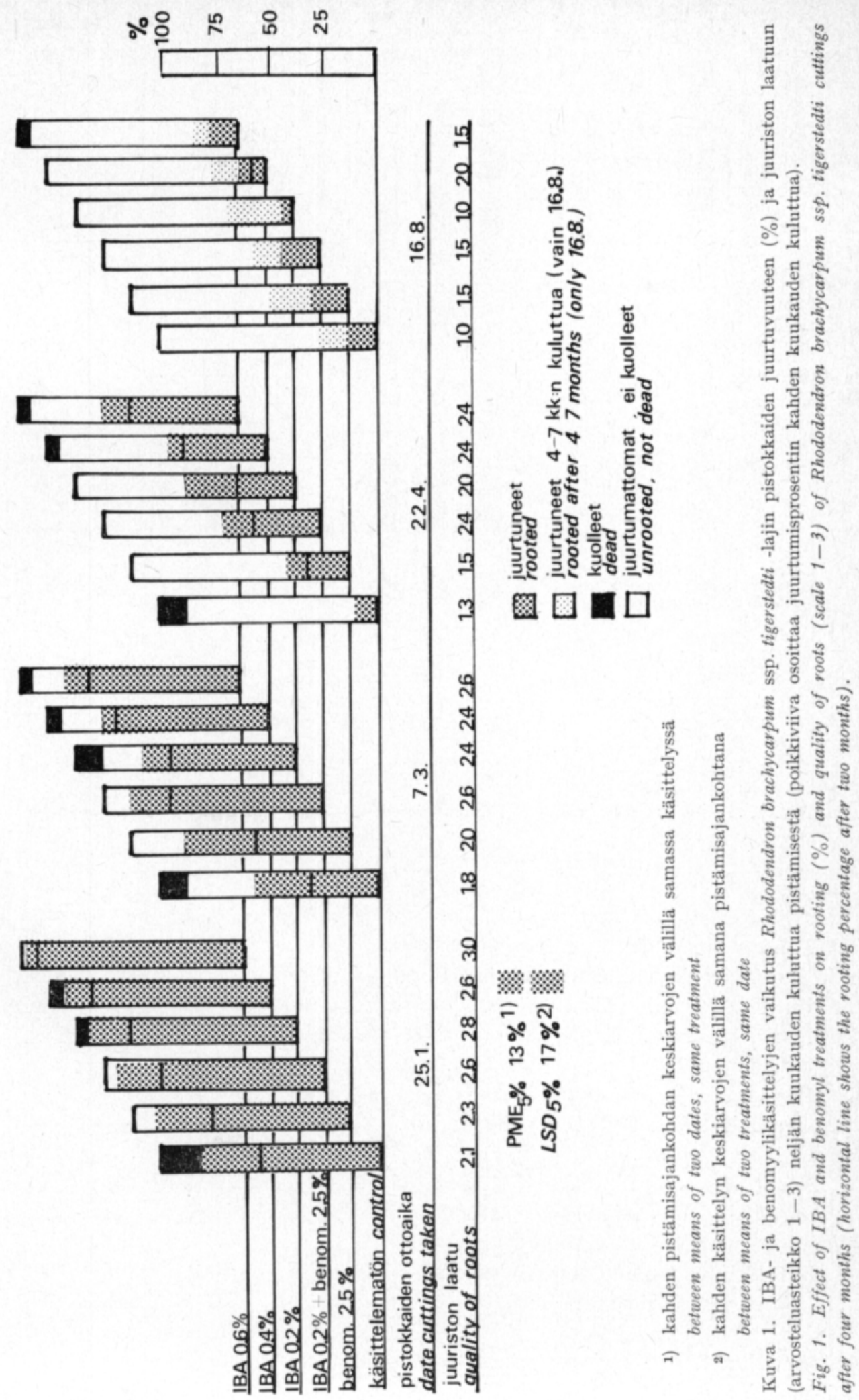



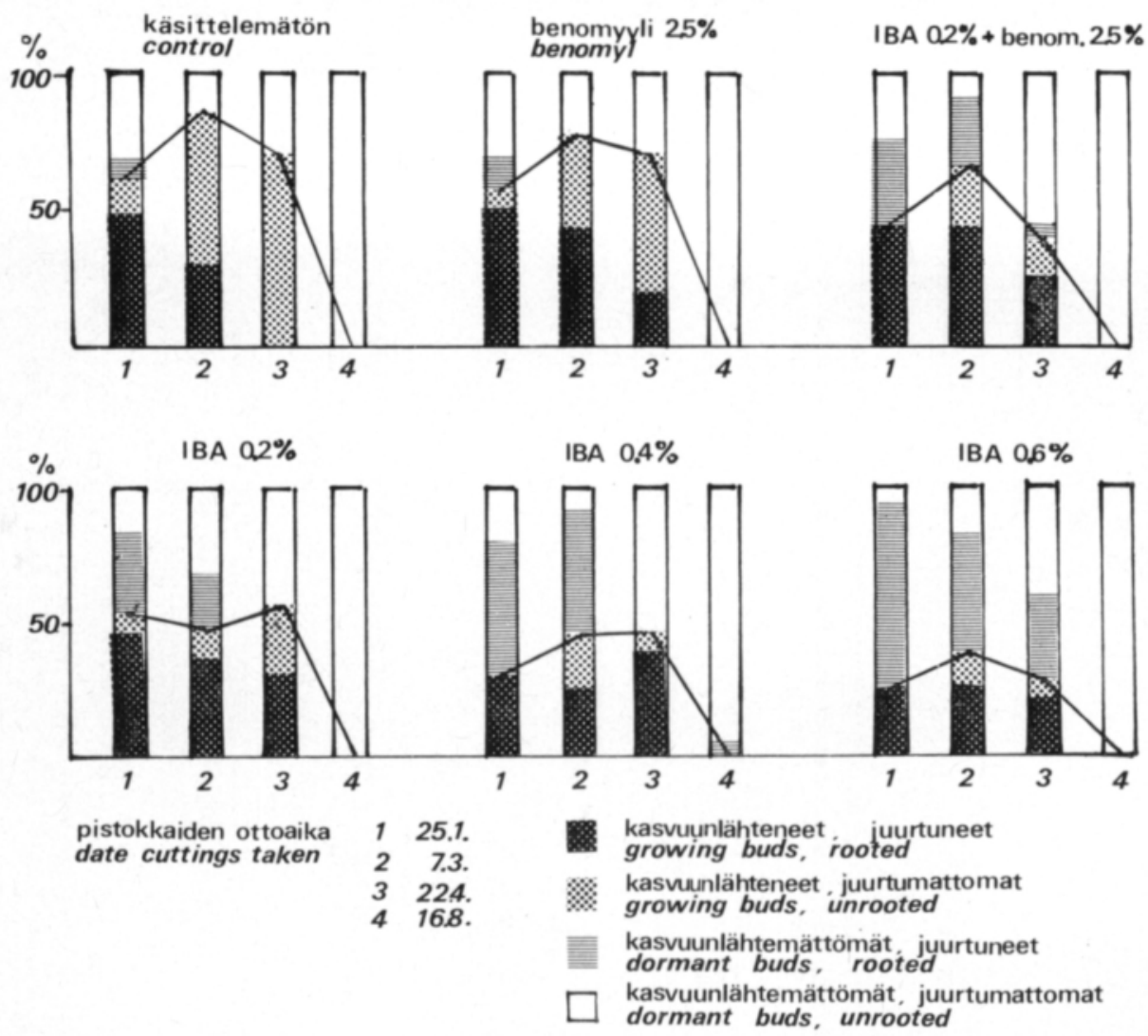

Kuva 2. Rhododendron brachycarpum ssp. tigerstedti -lajin pistokkaiden kasvuunlähtö ja juurtuminen kahden kuukauden kuluttua pistämisestä.

Fig. 2. Bud break and rooting of Rhododendron brachycarpum ssp. tigerstedti cuttings after two months.

Pistokkaiden kasvuunlähdön ja juurtumisen välinen suhde ilmenee kuvasta 2. Kahden kuukauden kuluttua pistämisestä kasvuunlähteneiden määrässä ei esiintynyt suuria eroja tammi-huhtikuun pistämiserissä. Silmujen puhkeaminen nopeutui kuitenkin maalis- ja huhtikuussa otetuilla pistokkailla tammikuuhun verrattuna. Tammikuussa pistetyt lähtivät kasvuun vasta hieman yli kuukauden kuluttua pistämisestä. Yksikään elokuussa otetuista pistokkaista ei lähtenyt kasvuun seitsemän kuukauden aikana. IBA-käsittelyn havaittiin hidastavan silmujen puhkeamista. Vaikutus oli sitä voimakkaampi, mitä korkeampaa IBA-väkevyyttä käytettiin. IBA-käsittelyn saaneista useimmat kasvuunlähteneet olivat juurtuneet. Sen sijaan suurin osa benomyylikäsitellyistä ja käsittelemättömistä kasvuunlähteneistä pistokkaista ei juurtunut maalis- ja huhtikuun pistämiserissä.

Pistokkaiden vuorokauden kestävän esikäsittelyn: boori- tai vesiliotuksen tai kuivavarastoinnin vaikutus juurtuvuuteen ilmenee kuvasta $3 \mathrm{~A}$. Esikäsittelyjen välillä ei havaittu merkitseviä eroja juurtuvuudessa. Keskimäärin parhaimman tuloksen sekä juurtuneiden määrän että juuriston laadun suhteen antoi booriliotus niillä pistokkailla, jotka eivät saaneet auksini- ja benomyyli- 
käsittelyä. Viimeksi mainituilla säilytys kuivana osoittautui paremmaksi kuin käsittelemättömillä. Kaikkien kuolleiksi merkittyjen tyvi oli mädäntynyt. IBA- ja benomyylikäsittelyn vaikutus juurtuvuuteen oli samansuuntainen kuin kuvassa 1. Pistokkaan tyven haavaleikkaus lisäsi juurtuneiden määrää, ja juuristo kehittyi tasapuoliseksi haavoituksen ansiosta (kuva $3 \mathrm{~B}$ ).

Rhododendron smirnowii -lajin pistokkaat otettiin tammikuun 25 p:nä ja maaliskuun 7 p:nä, ja käsittelyt olivat samat kuin $R h$. brachycarpum ssp. tigerstedti -lajilla kuvassa 1. Yksikään pistokas ei juurtunut kahden kuukau-

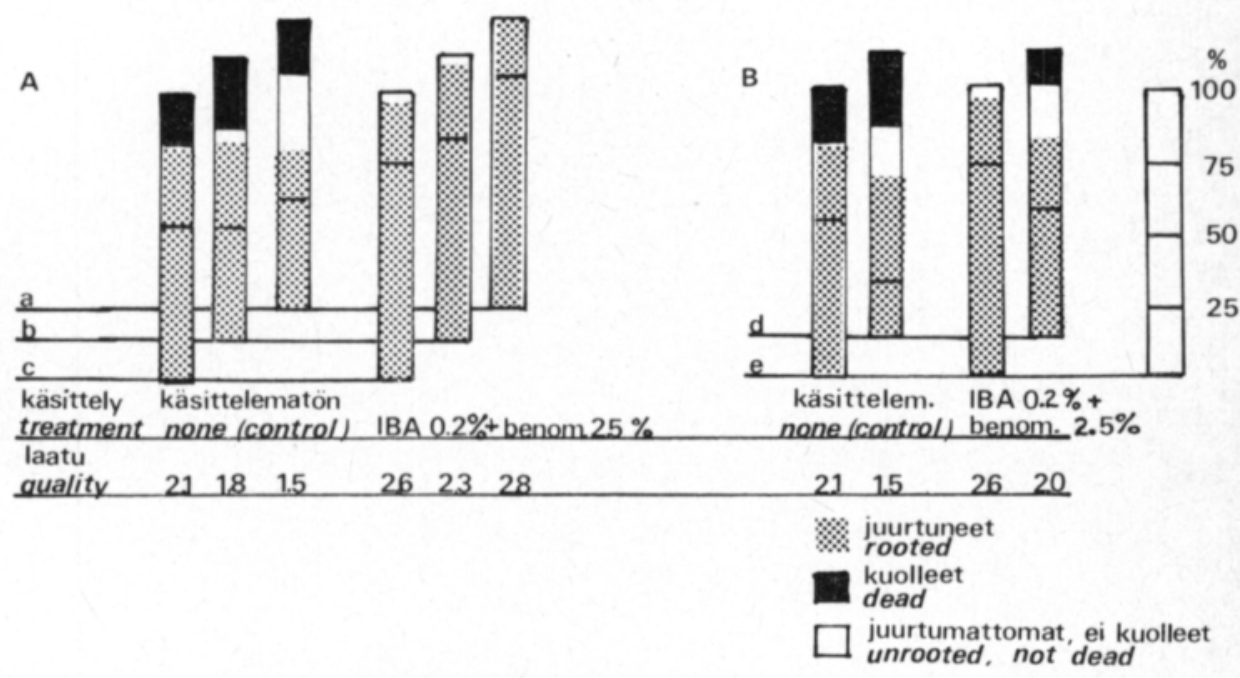

Kuva 3. Esikäsittelyjen vaikutus Rhododendron brachycarpum ssp. tigerstedti -lajin pistokkaiden juurtuvuuteen (\%) ja juuriston laatuun (arvosteluasteikko 1-3) neljän kuukauden kuluttua pistämisestä (poikkiviiva osoittaa juurtumisprosentin kahden kuukauden kuluttua). Pistokkaat otettiin 25.1.

A a varastointi kuivana $\left(+3-5^{\circ} \mathrm{C}\right) 1$ vrk

b vesiliotus $\left(20^{\circ} \mathrm{C}\right) 1$ vrk

c $0.01 \%$ booriliotus $\left(20^{\circ} \mathrm{C}\right) 1$ vrk

B d ei pistokkaan tyven haavoitusta

e pistokkaan tyven haavoitus

Fig. 3. Effect of pretreatment on rooting (\%) and quality of roots (scale 1-3) of Rhododendron brachycarpum ssp. tigerstedti cuttings after four months (horizontal line shows rooting percentage after two months). Cuttings were taken on January 25.

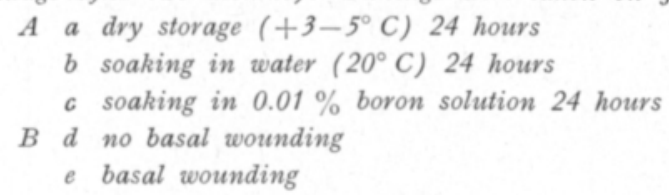

den aikana. Neljän kuukauden kuluttua pistämisestä $19 \%$ IBA- $(0.6 \%)$ sekä $13 \%$ IBA- $(0.2 \%)$ ja benomyylikäsittelyn $(2.5 \%)$ saaneista juurtui, mutta vain tammikuun pistämiserässä. Sen sijaan kallusta muodostui tyviin runsaasti. Suurin osa benomyylikäsitellyistä ja käsittelemättömistä pistokkaista lähti kasvuun kahden kuukauden aikana pistämisestä. 


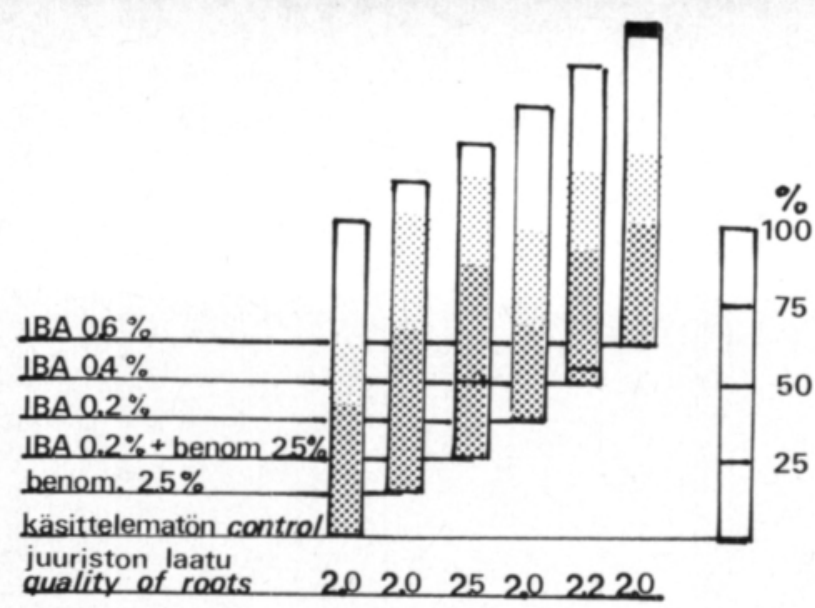

Kuva 4. IBA- ja benomyylikäsittelyjen vaikutus Rhododendron 'Cunningham's White' -lajin pistokkaiden juurtuvuuteen (\%) kahden, neljän ja seitsemän kuukauden kuluttua pistämisestä ja juuriston laatuun (arvosteluasteikko 1-3) neljän kuukauden kuluttua pistämisestä. Pistokkaat otettiin 16.8. Merkkien selitykset kuten kuvassa 1.

Fig. 4. Effect of IBA and benomyl treatments on rooting (\%) of Rhododendron 'Cunningham's White' cuttings after two, four and seven months, and on quality of roots (scale 1-3) after four months. Cuttings were taken on August 16. See figure 1 for explanation of marks.

Rhododendron 'Cunningham's White' -lajin pistokkaiden juurtuvuus ilmenee kuvasta 4. Myöskään tällä lajilla IBA- ja/tai benomyylikäsittely ei edistänyt merkitsevästi juurtumista elokuussa pidettynä neljän kuukauden kuluttua pistämisestä. Tyvien mätänemistä ei voitu havaita neljän kuukauden aikana pistämisestä, ei myöskään silmujen puhkeamista. Helmikuun lopulla tai maaliskuun alussa (6-7 kk pistämisestä) elossa olleiden pistokkaiden silmut puhkesivat. Kaikki kasvuunlähteneet olivat myös juurtuneet.

\section{Tulosten tarkastelu}

Rhododendron brachycarpum ssp. tigerstedti- ja Rh. smirnowii -lajit, joilla kokeiltiin useita pistämisajankohtia, juurtuivat parhaiten tammikuussa otettuina. Yleensä alppiruusun pistokkaat suositellaan otettaviksi loppukesällä tai keskitalvella (van VEEN 1971, van ELK 1973). Rh. 'Cunningham's White' ja erityisesti $R h$. brachycarpum ssp. tigerstedti -lajien pistokkaiden juurtuminen oli kuitenkin hidasta ja melko heikkoa loppukesällä pistettyinä, mutta pistokkaat säilyivät elinvoimaisina neljän kuukauden ajan. Heikkoon juurtumistulokseen saattoi vaikuttaa myös lyhyt päivä, sillä $R h$. mucronulatum -lajin pistokkaiden juurtuvuutta ja juuriston laatua on voitu parantaa pitkänpäivänkäsittelyllä (Waxman 1957, Lanphear \& Meahl 1961). Pitkä päivä saa tämän lajin lähtemään kasvuun (NITsch 1957, WAxman 1957). Myös $R h$. 
'Cunningham's White' -lajin kasvu riippuu vain päivänpituudesta. Lepotilan katkaisemiseksi se ei tarvitse kylmävaihetta (Doorenbos 1953). Saadut tulokset tukevat tätä, sillä elokuussa oettut pistokkaat lähtivät kasvuun helmi-maaliskuussa. Kaikki kasvuunlähteneet olivat myös juurtuneet. Juurtuneista kuitenkin $38 \%$ muodosti juuret vasta $4-7$ kuukauden (joulu-maaliskuu) kuluttua pistämisestä. Sen sijaan Rh. brachycarpum ssp. tigerstedtilajin elokuussa otettujen pistokkaiden silmut eivät olleet vielä puhjenneet maaliskuun puoleen väliin mennessä. Tosin useilla päätesilmun voitiin havaita turvonneen. Suurin osa pistokkaista kuoli alkuvuoden aikana. Saadut tulokset viittaavat siihen, että silmujen lepotilalla saattaa olla vaikutusta juurten muodostumiseen.

Pistokkaiden IBA-käsittely paransi juurtuvuutta sekä määrältään että laadultaan kevättalvella. IBA:n ansiosta pistokkaisiin saatiin tiivis juuripaakku, joka helpottaa koulintaa. IBA:n teho oli sitä parempi, mita myöhemmin kevättalvella pistettiin. Positiivinen vaikutus saattoi liittyä IBA:n silmujen nopean puhkeamisen ehkäisyyn. Versojen kasvu kilpailee ilmeisesti juurten alkujen muodostumisen kanssa. Tammikuussa silmujen hidas turpoaminen ja puhkeaminen mahdollistivat samanaikaisen juurten muodostumisen.

Elokuussa otettujen pistokkaiden juurtuvuutta IBA ei pystynyt parantamaan. Vastaavanlaisen havainnon LANPHEAR ja MeAHL (1961) tekivät juurruttaessaan $R h$. mucronulatum -lajin pistokkaita luontaisen lyhyen päivän aikana. Pitkässä päivässä IBA kuitenkin paransi juurtuvuutta syksyllä. Samoin sianpuolan ja variksenmarjan pistokkailla on todettu, ettei auksiinin puute ole syyskesällä juurtumista rajoittava tekijä. IBA-käsittely ja pitkä päivä edistivät juurten muodostumista vasta hieman ennen lepotilan päättymistä (Ylätalo 1978).

Benomyylikäsittely ehkäisi pistokkaiden tyvien mätänemistä ja siten pidensi pistokkaiden elinikää. Kevättalvella pistetyillä esiintyi tyven mätänemistä jo kahden kuukauden kuluttua pistämisestä, elokuussa otetuilla vasta neljän kuukauden jälkeen. Pistokkaiden vuotuisen kehityksen vaihe saattaa vaikuttaa tyven mätänemiseen, kuten sianpuolalla ja variksenmarjalla on todettu (Ylätalo 1978). Hoitink ja Schmitthenner (1970) sekä Carville (1971) ovat myös havainneet benomyylin edistävän alppiruusun pistokkaiden juurtumista.

Alppiruusun pistokkaiden booriliotuksen on osoitettu parantavan juuriston laatua (Medeiros 1973, Metsola 1975). Boori edistää juurten kasvua (HartMANN \& Kester 1975). Tämä todettiin erityisesti pistokkailla, joita ei käsitelty booriliotuksen jälkeen auksiinilla. Jos pistokkaat käsiteltiin IBA:lla ja benomyylillä, niiden säilytys kuivana ennen käsittelyä osoittautui paremmaksi kuin boori- tai vesiliotus. Tämä saattoi johtua siitä, että pistokkaat imivät auksiinia ja benomyyliä enemmän veden puutteesta johtuen.

Tyven haavoituksen vaikutus juurten muodostumiseen oli yhdenmukainen Heftin (1967) sekä Pierikin ja Steegmansin (1975) havaintojen kanssa. Haavoituksen edistävän vaikutuksen on arveltu johtuvan auksiinin ja hiilihydraattien kasautumisesta haavoitetulle alueella sekä hengityksen lisääntymisestä (HARTMAnN \& Kester 1975). Lisäksi vioittunut solukko stimuloituu tuottamaan etyleeniä, jonka on osoitettu edistävän jälkijuurten muodostumis- 
ta eräissä tapauksissa (KRISNAmoorThy 1970). Myös mekaaninen este, sklerenkyymirengas, voi vaikeuttaa ja hidastaa eräiden lajien juurten tunkeutumista tämän solukerroksen läpi (КАснснЕBA 1975).

Rhododendron brachycarpum ssp. tigerstedti -laji osoittautui helposti juurtuvaksi, kun pistokkaat otettiin vuoden alussa. Elokuussa pistettynä sitä paremmin juurtui $R h$. 'Cunningham's White' -laji, jota van ELK (1973) pitää melko helposti pistokkaista lisättävänä. Sen sijaan vain muutama $R h$. smirnowii -lajin pistokkaista kehitti juuria. Tälle lajille muodostui tyveen voimakas kallus, joka saattoi mekaanisesti estää hentojen juurien uloskasvua. Mahdollisesti korkeampi IBA-väkevyys ja voimakkaampi havoitus voisivat parantaa juurtumista.

Juurrutusolosuhteina paksu turvekerros ja suljettu muoviteltta osoittautuivat hyviksi ja helppohoitoisiksi. Touko-elokuussa korkeat lämpötilat aiheuttivat lieviä polttovioituksia lehtiin, mikä ilmeisesti osaltaan heikensi juurtumista. Menetelmä on käyttökelpoinen myös silloin, kun vesi ei laadullisesti sovellu alppiruusun sumumonistukseen.

\section{Tiivistelmä}

Selvitettiin pistämisajankohdan ja juurtumista edistävien käsittelyjen vaikutus kolmen Suomessa kestävimmäksi todetun alppiruusulajin (Rhododendron brachycarpum ssp. tigerstedti, Rh. 'Cunningham's White' ja Rh. smirnowii) pistokkaiden juurtuvuuteen. Pistokkaat juurrutettiin $40 \mathrm{~cm}$ paksulla turvealustalla muoviteltassa, joka aukaistiin kastelua varten kahden kuukauden välein.

Parhaimmaksi pistämisajankohdaksi osoittautui tammikuu. Tällöin silmujen hidas puhkeaminen mahdollisti samanaikaisen juurtumisen. Tammikuussa $R$ h. brachycarpum ssp. tigerstedti -laji juurtui $100 \%$ :sti, kun pistokkaat käsiteltiin $0.6 \%$ IBA:lla (käsittelemätön $79 \%$ ). Elokuun pistämiserissä IBA ei edistänyt juurtuvuutta.

Pistokkaiden tyvien benomyylikäsittely ehkäisi tyven mätänemistä ja paransi juurtuvuutta erityisesti yhdessä IBA:n kanssa käytettynä. Pistokkaan tyven haavoitus lisäsi myös juurtuneiden määrää ja paransi juuriston laatua.

Kokeessa olleista lajeista vaikeimmin juurrutettavaksi osoittautui $R h$. smirnowii.

KIRJALLISUUSLUETTELO

Carville, L. L. 1971. Effect of benomyl on rooting Rhododendron cuttings. Pl. Propagator 2: $19-20$.

Doorenbos, J. 1953. Orienterend onderzoek over het forceren van Forsythia en Rhododendron. Meded. Dir. Tuinb. 16: 533-543.

ELK, B. C. M. van 1973. Recent developments in the propagation of rhododendrons at Booskop. Intern. Pl. Prop. Soc. Comb. Proc. 23: 154-161.

Hartmann, H. T. \& Kester, D. E. 1975. Plant propagation. 662 p. 3rd Ed. New York.

HeFt, L. 1967. Stecklingsbewurzelung grossblumiger Rhododendron Sorten. Gartenwelt 14: $283-285$. 
Hoitink. H. A. J. \& Schmitthenner, A. F. 1970. Disease control in Rhododendron cuttings with benomyl or thiabendazole in hormone mixtures. Pl. Disease Rep. 54: 427-430.

КаснсневA, J. L. 1975. Anatomical aspects of the formation and growth of roots in stem cuttings of some species of Hibiscus. I Stem anatomy and its relation to the formation and growth of roots. Hort. Res. 14: 57-67.

Krisnamoorthy, H. N. 1970. Promotion of rooting in mung bean hypocotyl cuttings with Ethrel, an ethylene-releasing compound. Pl. and Cell Physiol. 11: 979-982.

LANphear, F. O. \& MEAhL, R. P. 1961. The effect of various photoperiods on rooting and subsequent growth of selected woody ornamental plants. Proc. Amer. Soc. Hort. Sci. 77: $620-634$.

Medeiros, M. J. 1973. All year propagation of rhododendrons by cuttings. Intern. Pl. Prop. Soc. Comb. Proc. 23: 474-479.

Metsola, P. 1975. Alppiruusun pistokaslisäys muoviteltassa paksussa turvekerroksessa. Laudaturtyő. Hels. Yliop. Puutarhatieteen laitos. 77 p.

Nitsch, J. P. 1957. Growth responses of woody plants to photopriodic stimuli. Proc. Amer. Soc. Hort. Sci. 70: $512-525$.

Pierik, R. L. M. \& Steegmans, H. H. M. 1975. Analysis of adventitious root fromation in isolated stem explants of Rhododendron. Sci. Hort. 3:1-20.

VEEN, T. van 1971. The propagation and production of rhododendrons. Amer. Nurseryman 133 (8): $15-16,52-58$.

Waxman, S. 1957. The development of woody plants as affected by photoperiodic treatments. $\mathrm{Ph}$. D. Thesis. Cornell Univ. 193 p. (ref. Nitsch, J. P. 1957).

Ylätalo, M. 1978. Arctostaphylos uva-ursi (L.) Spreng. ja Empetrum nigrum L. -lajien pistokkaiden juurtuminen ja indoli-3-voihapon (IBA) vaikutus vuotuisen kehityksen eri vaiheissa. Lisensiaattityö. Hels. Yliop. Puutarhatieteen laitos. 119 p.

Käsikirjoitus saapunut 6.4.1979 